\title{
Pengaruh Model Pembelajaran Kooperatif Teknik Two Stay Two Stray (TSTS) terhadap Hasil Belajar Biologi Siswa
}

\section{The Effect of Two Stay Two Stray (TSTS) Technique of Cooperative Learning Model toward Students' Biology Learning Outcomes}

\author{
Eva Novika Sari, Reduk Nilawarni, Erna Heryanti \\ Corresponding author; email: ukhti_ms@yahoo.com
}

\begin{abstract}
Learning activities determines the achievement of learning aims and objectives. One of the objectives can be reflected in higher students' learning result. The improvement may occur using Two Stay Two Stray Technique of Cooperative Learning Model since students are encouraged to learn together and help each other in groups. The research aimed to determine the effect of Two Stay Two Stray (TSTS) technique of Cooperative Learning Model on Students' Biology Learning Outcomes on the ecosystem topic. This research was carried out at SMAN 2 Tangerang on May to June 2012 using a quasi-experimental method. Two science classes at grade 10 were selected by purposive sampling technique, class X-7 as the experimental group and class X-8 as the control group. An overall of 36 students of each class was selected by simple random sampling. Data obtained by using instruments of multiple choice question test and affective Attitude Scale. The result of Normality testing of Kolmogorov-Smirnov test and homogeneity testing of F-test showed a normal distribution and homogenous data. The average Biology study result of experimental group was 79.1 while of control group was 74.3. Based on the result, it can be concluded that Two Stay Two Stray (TSTS) technique of Cooperative Learning Model affected Students' Biology Learning Outcomes.
\end{abstract}

Keyword: biology learning outcomes, ecosystem, two stay two stray technique of cooperative learning model

\section{Pendahuluan}

Kurikulum 2004 yang lebih dikenal dengan Kurikulum Berbasis Kompetensi (KBK) merupakan kurikulum yang menekankan padapengembangan kemampuan melakukan (kompetensi), sehingga hasilnya dapat dirasakan oleh peserta didik berupa penguasaan terhadap seperangkat kompetensi tertentu (Susilo, 2008). Kurikulum Berbasis Kompetensi menekankan pada pembelajaran yang lebih variatif baik dalam metode pembelajaran, strategi belajar, sumber belajar, maupun alat dan media pembelajaran yang secara keseluruhan membuat siswa mampu mencapai kompetensi belajar.

Biologi merupakan cabang ilmu yang mempelajari mengenai makhluk hidup. Pembelajaran biologi memiliki beberapa materi pelajaran seperti materi ekosistem yang membutuhkan strategi belajar yang tepat. Pemahaman siswa didapatkan tidak cukup hanya dengan memahami konsep yang berasal dari guru, siswa juga perlu berkembang secara mandiri melalui proses berpikir dan bekerja sama.

Keberhasilan pembelajaran tidak terlepas dari kemampuan guru dalam mengembangkan model pembelajaran. Model pembelajaran yang tepat pada dasarnya bertujuan menciptakan kondisi belajar yang efektif dan menyenangkan sehingga siswa dapat meraih hasil belajar dan prestasi yang optimal (Aunurrahman, 2009).

Salah satu model pembelajaran yang dapat digunakan dalam pembelajaran biologi khususnya pada materi ekosistem adalah pembelajaran kooperatif (Cooperative Learning). Pembelajaran kooperatif adalah suatu pengajaran dimana murid bekerja dalam kelompok kecil heterogen untuk saling membantu satu samalain dalammenyelesaikan tugas (Isjoni, 2010). Pembelajaran Kooperatif 
dikembangkan untuk mencapai setidaknya tiga tujuan pembelajaran, yaitu peningkatan kemampuan akademik, penerimaan terhadap keragaman, dan pengembangan keterampilan sosial (Ibrahim, 2000 dalam Isjoni, 2010).

Salah satu teknik Pembelajaran Kooperatif adalah Two Stay Two Stray (TSTS). Pembelajaran dengan teknik ini memberikan kesempatan kepada kelompok untuk membagikan hasil dan informasi ke kelompok lain (Lie, 2008). Para siswa diharapkan dapat saling membantu, saling mendiskusikan dan berargumentasi untuk mengasah pengetahuan yang mereka kuasai dan menutup kesenjangan dalam pemahaman masing-masing (Slavin, 1984 dalam Sholihatin, 2008). Kemampuan akademik siswa akan meningkatkan karena adanya kerja sama antarsiswa yang berkemampuan tinggi maupun siwa yang berkemampuan rendah. Berdasarkan latar belakang tersebut maka dilakukanlah penelitian ini untuk mengetahui pengaruh Model Pembelajaran Kooperatif Teknik Two Stay Two Stray (TSTS) terhadap hasil belajar Biologi siswa.

\section{Metode Penelitian}

Penelitian ini bertujuan untuk mengukur hasil belajar biologi dan menganalisis pengaruh model pembelajaran kooperatif teknik Two Stay Two Stray (TSTS) pada materi ekosistem terhadap hasil belajar biologi siswa SMA Negeri 2 Tangerang pada semester genap tahun ajaran 2011/2012 dalam kurun waktu antara bulan Mei-Juni 2012.

Penelitian ini menggunakan metode kuasi eksperimen. Populasi target pada penelitian ini adalah seluruh siswa SMAN 2 Tangerang. Populasi terjangkaunya adalah kelas $\mathrm{X}$ yang dipilih secara purposive sampling. Sampel dalam penelitian ini adalah sebanyak dua kelas yaitu satu kelas perlakuan (X-7) dan satu kelas kontrol (X-8) yang dipilih secara simple random sampling.

Data pada penelitian ini didapatkan melalui beberapa cara pengumpulan data, yaitu penyebaran tes hasil belajar biologi ranah kognitif dan afektif yang telah diuji validitas dan realibiltas, serta observasi guru dan siswa pada saat pembelajaran.
Data yang telah diperoleh dari tes hasil belajar biologi, akan dianalisis pertama dengan uji prasyarat analisis data berupa: uji normalitas dan uji homogenitas dengan taraf signifikansi $5 \%$ atau $(\alpha=0,05)$. Tahap berikutnya dilakukan uji hipotesis menggunakan uji t dengan taraf signifikansi $5 \%(\alpha=0,05)$.

\section{Hasil}

a. Skor Hasil Belajar Biologi Siswa Kelas Eksperimen

Hasil belajar ranah kognitif siswa kelas eksperimen diperoleh nilai rata-rata siswa sebesar 83,4 dengan nilai tertinggi yang diperoleh sebesar 97,1 dan nilai terendah sebesar 54,3. Nilai hasil belajar ranah afektif siswa rata-rata sebesar 74,9 dengan skor tertinggi yang diperoleh sebesar 88,8 sedangkan skor terendah sebesar 67,2

Hasil belajar Biologi kelas eksperimen secara keseluruhan setelah dirata-ratakan antara kognitif dan afektif yaitu 79,1 dengan nilai tertinggi, yaitu 91,5 dan nilai terendah 61,2. Berikut ini adalah gambar diagram batang dari distribusi frekuensi hasil belajar Biologi kelas eksperimen:

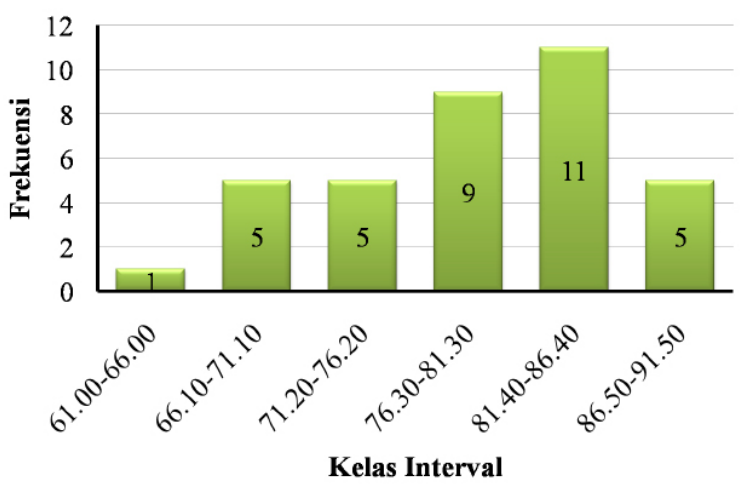

Gambar 1. Diagram batang distribusi frekuensi hasil belajar Biologi kelas eksperimen

Berdasarkan Gambar 1, dapat terlihat bahwa di kelas eksperimen untuk hasil belajar menunjukkan frekuensi terbesar pada interval 81,4 - 86,4 yaitu sebanyak 11 orang $(30,6 \%)$, sedangkan frekuensi terkecil terdapat pada interval 61,0 66,0 yaitu sebanyak 1 orang (2,8 \%). Simpangan baku sebesar 7,12. 
b. Skor Hasil Belajar Belajar Biologi Siswa Kelas Kontrol

Hasil belajar ranah kognitif siswa kelas kontrol diperoleh nilai rata-rata siswa sebesar 76,1 dengan nilai tertinggi yang diperoleh sebesar 100 dan nilai terendah sebesar 57,1. Nilai hasil belajar ranah afektif siswa rata-rata sebesar 72,5 dengan skor tertinggi yang diperoleh sebesar 87,1 sedangkan skor terendah sebesar 55,2.

Hasil belajar Biologi kelas kontrol secara keseluruhan setelah dirata-ratakan antara kognitif dan afektif yaitu 74,3 dengan nilai tertinggi, yaitu 89,2 dan nilai terendah 60,5. Berikut ini adalah gambar diagram batang dari distribusi frekuensi hasil belajar Biologi kelas kontrol:

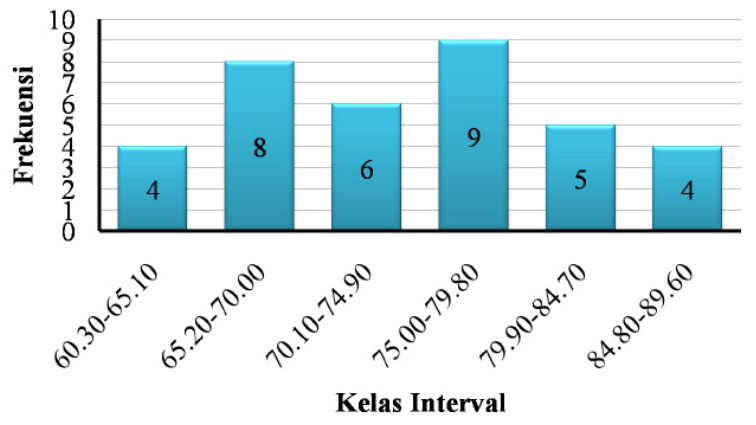

Gambar 2. Diagram batang distribusi frekuensi hasil belajar Biologi Kelas Kontrol

Berdasarkan distribusi frekuensi pada gambar 2, terlihat bahwa frekuensi terbesar pada interval 75,0 - 79,8 yaitu sebanyak 9 orang $(25,0 \%)$, sedangkan frekuensi terkecil terdapat pada interval $60,3-65,1$ dan 84,8 - 89,6 yaitu sebanyak 4 orang (11,1\%). Simpangan baku sebesar 7,84.

c. Perbedaan Rata-Rata Skor Hasil Belajar Siswa Kelas Eksperimen dan Kelas Kontrol

Perbedaan nilai rata-rata hasil belajar Biologi secara keseluruhan diperoleh rata-rata hasil belajar Biologi pada kelas eksperimen lebih besar dibandingan dengan rata-rata hasil belajar Biologi kelas kontrol. Perbedaan nilai rata-rata siswa dapat dilihat pada gambar 3 .

d. Hasil Observasi

Hasil observasi keterlaksanaan pembelajaran oleh guru di kelas eksperimen dengan model pembelajaran kooperatif teknik Two Stay Two ISSN : 08532451
Stray (TSTS) diperoleh persentase keterlaksanaan pada setiap pertemuan berturut-turut sebesar $86,3 \%$ dan $78,4 \%$. Rata-rata persentase keterlaksanaan semua pertemuan sebesar $82,3 \%$. Hasil observasi keterlaksanaan pembelajaran oleh guru pada kelas kontroldiperoleh persentase keterlaksanaan pada setiap pertemuan berturut-turut sebesar $89,6 \%$ dan 79,2\%. Rata-rata persentase keterlaksanaan semua pertemuan sebesar $84,7 \%$. Hasil observasi keterlaksanaan pembelajaran oleh guru pada kelas kontrol lebih besar, yaitu $84,7 \%$ daripada kelas eksperimen, yaitu $82,3 \%$.

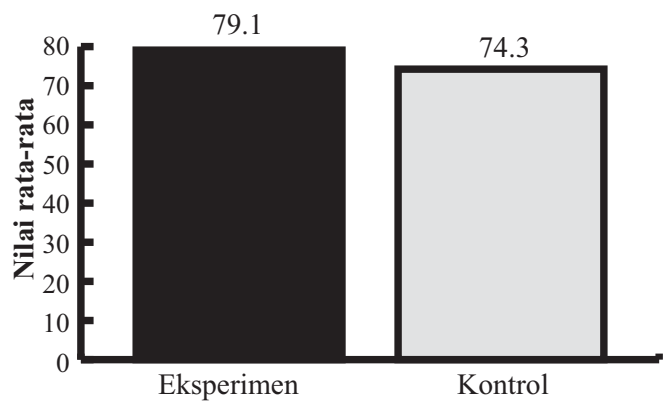

Gambar 3. Diagram batang perbandingan rata-rata nilai hasil belajar biologi kelas eksperimen dan kelas kontrol

\section{Pembahasan}

Hasil perhitungan nilai rata-rata kelas eksperimen dan kelas kontrol menunjukkan bahwa rata-rata hasil belajar biologi siswa kelas eksperimen lebih tinggi daripada kelas kontrol. Hal ini menunjukkan tolak Ho yang artinya terdapat pengaruh model pembelajaran kooperatif teknik Two Stay Two Stray terhadap hasil belajar biologi siswa pada materi ekosistem. Hal ini sesuai dengan kelebihan pembelajaran kooperatif teknik TSTS yang dapat meningkatkan prestasi siswa karena pada teknik ini memberikan kesempatan kepada siswa untuk lebih banyak berinteraksi kepada siswa lain sehingga informasi yang didapatkan siswa menjadi lebih beragam untuk memperkaya pemahaman pengetahuan yang mereka kuasai. (Aminah dalam Susanti, 2009).

Siswa tidak hanya berdiskusi dengan satu kelompok saja tetapi juga berbagi informasi dengan kelompok yang lain dengan adanya kelompok tamu., sehingga intensitas keterlibatan siswa lebih meningkat. Siswa 
saling bertukar informasi antar kelompok. Peningkatan intensitas keterlibatan siswa dalam proses pembelajaran akan berpengaruh pada keberhasilan belajar siswa (Aunurrahman, 2009).

Nilai hasil belajar kognitif pada kelas eksperimen lebih besar dibandingkan kelas kontrol. Hasil belajar ini terjadi karena siswa menjadi lebih aktif dalam proses pembelajaran. Siswa dapat berpendapat atau memberikan masukan, mampu menjawab pertanyaan yang disampaikan oleh teman, mampu memberikan tanggapan/sanggahan pada saat teman lain berpendapat, serta siswa mampu menjelaskan hasil kunjungan ke kelompok lain kepada kelompok asal. Siswa dilibatkan aktif dalam proses pembelajaran, yang menjadikan mereka tidak hanya sebagai penerima informasi, tetapi juga sebagai pencari informasi dan pelaku, sehingga dapat berpengaruh terhadap hasil belajarnya. Siswa yang lebih pandai mengajari siswa yang kurang pandai sehingga memperoleh pemahaman yang lebih baik. Siswa yang lebih pandai memperoleh peningkatan pemahaman juga, karena dengan mengajari temannya, siswa yang pandai akan berpikir lebih mendalam tentang materi yang disampaikan (Arends, 2007).

Kelaskontrolmelakukan pembelajaran dengan model Pembelajaran Kooperatif teknik STAD mendapatkan nilai rata-rata yang lebih rendah dari kelas eksperimen. Rendahnya rata-rata hasil belajar biologi siswa pada kelas kontrol diduga karena interaksi antar siswa menjadi lebih terbatas disebabkan tidak terjadinya pertukaran kelompok seperti pada kelas eksperimen. Hal ini penting, sebab jika kurangnya interaksi antar siswa akan membuat pengetahuan siswa menjadi terbatas hanya dari kelompoknya saja. Padahal untuk mengoptimalisasikan hasil belajar biologi, siswa perlu terlibat aktif dalam proses pembelajaran dengan melihat berbagai gagasan yang berbeda dari siswa lain sehingga memungkinkan siswa untuk mengonstruksikan pengetahuan dan memberdayakan gagasan orang lain itu untuk meningkatkan hasil belajar siswa tersebut (Eggen \& Kauchak, 2007 dalam Jacobsen, 2009).
Siswa pada kelas kontrol yang tidak melakukan pertukaran kelompok, maka jika terjadi keterbatasan informasi dalam kelompoknya atau kesalahan di dalam kelompoknya sendiri, maka akan sedikit sekali mendapatkan kesempatan untuk mendapatkan pengetahuan yang lebih karena tidak terjadinya pertukaran kelompok sehingga berakibat pada perolehan pengetahuan yang terbatas yang akhirnya akan berdampak pada hasil belajar siswa tersebut. Hal ini terbukti pada hasil belajar siswa kelas kontrol yang lebih rendah daripada kelas eksperimen.

Hasil belajar ranah afektif dilakukan dengan memberikan angket hasil belajar afektif yang sama kepada kelas kontrol dan kelas eksperimen. Berdasarkan data diperoleh rata-rata skor afektif kelas eksperimen lebih tinggi dari kelas kontrol. Hal ini disebabkan karena model pembelajaran kooperatif teknik TSTS dapat menciptakan sikap yang melibatkan siswa berinteraksi satu sama lain terutama dalam kelompok maupun dengan kelompok lain. Siswa akan lebih banyak belajar melalui proses, kerja dalam kelompok dan berbagi pengetahuan, serta tanggung jawab individu dan kelompok yang merupakan kunci keberhasilan pembelajaran (Snow, 1977 dalam Cecil, 2007). Selain itu siswa lebih aktif berkontribusi pada kelompoknya dalam rangka memenuhi kewajibannya dalam kelompok. Suasana diskusi menjadi lebih hidup, saling membantu dan bekerja sama.

Berbeda dengan kelas eksperimen, kelas kontrol memperoleh skor rata-rata afektif yang lebih rendah dibanding kelas eksperimen. Hal ini disebabkan karena pada kelas kontrol kurang adanya interaksi antar siswa karena tidak terjadinya pertukaran kelompok. Siswa akan lebih pasif karena siswa bekerja dalam kelompok yang itu-itu saja, hal ini dapat menyebabkan nilai afektif kelas kontrol lebih rendah dari kelas eksperimen.

Hasil observasi keterlaksanaan pembelajaran oleh guru pada kelas kontrol lebih besar daripada kelas eksperimen. Perbedaan ini terjadi karena guru lebih mempersiapkan dan memperhatikan setiap tahapan pembelajaran karena jam pelajaran biologi kelas kontrol berlangsung di jam 
terakhir. Hasil keterlaksanaan pembelajaran yang lebih tinggi ini tidak berpengaruh terhadap hasil belajar biologi kelas kontrol, dimana hasil belajar biologi kelas kontrol lebih rendah daripada kelas eksperimen.

Perbedaan nilai rata-rata hasil belajar siswa antara kelas eksperimen dan kelas kontrol pada penelitian ini membuktikan bahwa pembelajaran melalui model pembelajaran koopeatif Teknik Two Stay Two Stray dapat digunakan sebagai salah satu model pembelajaran untuk meningkatkan pemahaman siswa terhadap materi pelajaran. Penelitian ini memiliki keterbatasan yaitu hanya melihat pengaruh model pembelajaran kooperatif teknik TSTS terhadap hasil belajar biologi siswa pada ranah kognitif dan afektif saja. Keterbatasan tersebut diharapkan dapat ditiadakan pada penelitian selanjutnya.

\section{Kesimpulan}

Berdasarkan hasil penelitian yang telah dilakukan maka dapat disimpulkan bahwa terdapat pengaruh model pembelajaran kooperatif teknik Two Stay Two Stray (TSTS) terhadap hasil belajar biologi siswa SMAN Negeri 2 Tangerang.

\section{Daftar Pustaka}

Arends, Richard I. (2007). Learningto teach, Belajar untuk Mengajar, Jilid 2 edisi 7. Terj,oleh Helly Prajitno Soetjipto dan Sri Mulyantini Soetjipto, Yogyakarta: Pustaka Pelajar.

Aunurrahman. (2009). Belajar dan Pembelajaran. Bandung: Alfabeta.

Isjoni. (2010). Pembelajaran Kooperatif. Yogyakarta: Pustaka Pelajar.

Jacobsen, David A, Paul D. Eggen, dan Donald P. Kauchak. (2009). Methods for Teaching. Yogyakarta: Pustaka Pelajar.

Lie, Anita. (2008). Cooperative Learning. Jakarta: PT.Grasindo.

Sholihatin, Etin dan Raharjo. (2008). Cooperatif Learning. Jakarta: PT.Bumi Aksara.

Susanti, Afni. (2009). Penerapan Pola PBMP (Pemberdayaan Berpikir Melalui Pertanyaan) dalam Metode TSTS (Two Stay Two Stray) untuk Meningkatkan Aktivitas dan Hasil Belajar Biologi Siswa. Malang: UNM.

Susilo, M. Joko. (2008). Kurikulum Tingkat Satuan Pendidikan (Manajemen Pelaksanaan dan Kesiapan Sekolah menyongsongnya). Pustaka Belajar: Yogyakarta. 